\title{
PERANCANGAN APLIKASI PENJUALAN PUPUK DENGAN MENGGUNAKAN MICROSOFT VISUAL FOXPRO 8.0 PADA KOPERASI MITRA SEHATI KOTA AGUNG TANGGAMUS
}

\author{
Yutshi Aprilinda \\ Program Studi Teknik Informatika \\ Fakultas Ilmu Komputer \\ Universitas Bandar Lampung \\ Jln. Z.A. Pagar Alam No.26 Labuhan Ratu Bandar Lampung 35142 \\ Telp. (0721) 701463, (0721) 701979 Fax. (0721) 701467 Web. www.ubl.ac.id
}

\begin{abstract}
Abstrak
Setiap perusahaan atau badan koperasi yang usahanya bergerak dalam bidang penjualan pada umumnya mempunyai kesulitan dalam menginventariskan barang-barang dagangan dan juga pembukuan sebab hampir setiap hari terjadi perputaran barang-barang yang mereka pasarkan atau yang mereka jual. Kesulitan tersebut bisa terjadi karena kurangnya ketelitian perusahaan atau badan koperasi menangani masalah yang ada, hal ini terjadi akibat kurangnya fasilitas yang menangani tentang penjualan, kesalahan atau akibat kurangnya informasi yang masuk maupun infromasi yang keluar pada perusahaan tersebut.

KOPERASI MITRA SEHATI salah satu badan koperasi yang berada di Kota Agung Tanggamus yang bergerak dibidang penjualan pupuk. Sistem penjualan pada koperasi ini masih menggunakan sistem manual, penjualan pupukk merupakan faktor penting yang harus diperhatikan dan ditangani secara baik dalam koperasi ini. Dengan adanya komputer dalam usaha penjualan pupuk, diharapkan dapat meminimalisasi kesalahan / tidak terjadi kesalahan dalam menangani penjualan.
\end{abstract}

Kata Kunci : Produk, Penjualan, Aplikasi

\section{PENDAHULUAN}

Dengan kemajuan teknologi yang semakin canggih sekarang ini, maka kebutuhan manusia akan informasi menjadi sangat penting. Banyak sekali teknologi-teknologi yang dapat membantu dalam pekerjaan manusia, salah satu contohnya yaitu komputer. Komputer merupakan alat bantu yang dapat memberikan hasil yang optimal dibandingkan dengan pekerjaan yang dilakukan secara manual. Komputer digunakan tidak hanya sebatas untuk pengolahan data dan angka saja, tetapi juga menyangkut bidang aplikasi. Teknologi komputer dapat memberikan suatu hasil dari informasi secara baik, Informasi akan menjadi berguna apabila mempunyai sistem informasi yang bagus dan sumber daya manusia yang dapat bekerja dengan cepat, tepat dan efisien.Di dalam suatu badan koperasi sangat diperlukan pula sistem informasi yang sangat baik. Untuk memenuhi kebutuhan informasi didalam suatu badan koperasi khususnya pada Koperasi MITRA SEHATI, maka diperlukan sebuah sistem informasi yang telah terkomputerisasi di dalam sebuah program aplikasi, sehingga sumber data yang tersedia dapat dipergunakan seoptimal mungkin oleh setiap bagian dalam badan koperasi tersebut.

\subsection{Identifikasi Masalah dan Permasalahan.}

Adapun masalah yang ditemukan adalah :

1. Kesulitan dalam mengidentifikasi barang maupun pelanggan

2. Kesulitan dalam pelaksanaan pembukuan penjualan bulanan.

3. Proses pengolahan data penjualan masih menggunakan sistem manual. Oleh karena itu masih banyak terdapat orang - orang yang tidak bertanggu jawab dalam hal penjualan pupuk

\subsection{Batasan Masalah}


Agar pembahasan laporan ini tidak meluas pada permasalahan lainnya, maka penulis memberikan batasan masalah sebagai berikut :

1. Perancangan aplikasi penjualan yang diperlukan untuk mendukung penjualan pupuk pada KOPERASI MITRA SEHATI

2. Pembuatan program aplikasi penjualan dengan MICROSOFT VISUAL FOXPRO 8.0 yang dibutuhkan dalam penjualan pupuk pada KOPERASI MITRA SEHATI

\subsection{Maksud Penulisan dan Tujuan Penulisan.}

\subsubsection{Maksud Penulisan.}

1. Menganalisa proses - proses yang dilakukan untuk mendukung kegiatan penjualan pupuk pada KOPERASI MITRA SEHATI.

2. Menganalisa program aplikasi penjualan yang dibutuhkan dalam penjualan dengan Microsoft Visual Foxpro 8.0 sehingga dapat mempermudah transaksi penjualan pupuk pada KOPERASI MITRA SEHATI.

3. Sebagai salah satu syarat dalam menyelesaikan S1 Teknik Informatika Universitas Bandar Lampung.

\subsubsection{Tujuan Penulisan.}

Adapun tujuan yang didapat dari penulisan yang dilakukan adalah :

1. Untuk mendapatkan solusi yang praktis, efisien, dan akurat dalam melakukan proses penjualan pupuk pada KOPERASIMITRA SEHATI.

2. Membuat suatu program aplikasi penjualan yang berguna dalam melakukan transaksi penjualan pupuk di KOPERASIMITRA SEHATI.

3. Sebagai referensi pada program studi Teknik Informatika Universitas Bandar Lampung.

\section{LANDASAN TEORI}

\subsection{Pengertian Aplikasi}

Definisi aplikasi menurut kamus komputer adalah program software atau paket program yang dibuat untuk melaksanakan suatu fungsi bagi pengguna (program siap pakai). Aplikasi akan menggunakan sistem operasi (OS) komputer yang mendukung. Biasanya istilah aplikasi dipakai dengan nama program, misalnya aplikasi $M S$
Word.

\subsection{Proses Perangkat Lunak}

Sebuah kerangka kerja proses umum dibangun dengan mendefinisikan sejumlah kecil aktivitas kerangka kerja yang bisa diaplikasikan ke semua proses perangkat lunak, tanpa melihat ukuran atau kompleksitasnya. Berikut merupakan Proses perangkat lunak

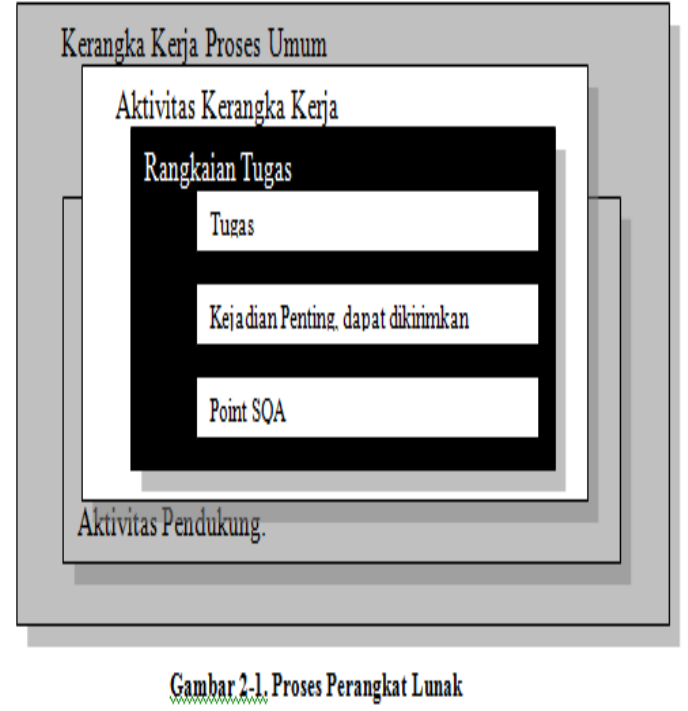

\subsection{Tahap-tahap Perancangan Program}

Untuk membuat / menyusun suatu program yang besar dan komplek, pemrograman membutuhkan beberapa tahapan-tahapan yang sistematis dan terpadu, yaitu :

\section{Definisi Masalah}

Pendefinisian masalah untuk mendapatkan pemahaman tentang permasalahan yang ada, sehingga akan diperoleh asumsi-asumsi yang benar untuk dapat memecahkan permasalahan. Langkah-langkah pendefinisian masalah adalah sebagai berikut :

a. Pemahaman permasalahan.

Pemahaman permasalahan sangat penting, karena sering sekali terjadi persepsi yang berbeda didalam pemahaman permasalahan, sehingga akhirnya tidak mendapatkan pemecahan masalah yang tepat.

b. Identifikasi masalah

Disini pemrogram dapat mengungkapkan kemungkinan permasalahan yang muncul pada saat pembuatan program dilaksanakan.( Indra Yatini B : $2001: 6$ ) 


\section{Analisis Kebutuhan}

Analisis kebutuhan merupakan aktifitas komunikasi yang paling intensif dan merupakan tugas utama yaitu, pengenalan masalah eveluasi masalah serta sistesis yang merupakan 2 tugas yang harus dikuasai dengan mahir untuk mendapatkan informasi yang dibutuhkan. Ada beberapa hal yang mendasari timbulnya permasalahan pada tahap analisis kebutuhan, antara lain :

a. Komunikasi yang jelek antara pemakai dan analisis.

b. Teknik yang digunakan kurang baik dan alat bantu yang digunakan juga kurang baik sehingga spesifikasi kurang baik dan kurang akurat.

c. Kecendrungan kurang memperpendek waktu analisis. Gagal dalam mempertimbangkan alternatif pemecahan masalah.

( Indra Yatini B : $2001: 2$ )

\section{Desain Algoritma}

Desain algoritma dibuat sama dengan menuliskan langkah-langkah dalam pemecahan masalah yang ada, karena algoritma dibuat dengan tujuan untuk menyelesikan sutu permasalahan. Algoritma yang dibuat tidak langsung jadi dan harus dikaji terus-menerus, sehingga akan diperoleh algoritma yang paling relevan, karena harus memiliki kebenaran secara logika sebelum siap untuk diimplementasikan dalam bentuk program.Fase dari desain algoritma terlengkap bila telah mempumyai suatu deskripsi penuh, dan bila kajian yang telah dilakukan tidak lagi menyingkap permasalahan, berat telah siap untuk melngkah dengan pengkodean. ( Indra Yatini B : $2001: 7,8$ )

\section{Pengkodean}

Pengkodean adalah kemudahan yang didapat pemeliharaan maupun dalam mengerti kode sumber yang telah dibuat. Pengkodean menekankan kepada kesederhanaan dan kejelasan pengkodean meliputi . (Indra Yatini B : $2001: 8$ )

\section{a. Dokumentasi kode}

Dokumentasi kode atau dokumentasi program sumber dimulai dengan pemilihan identifier ( variable dan label ), kemudian dilanjutkan dengan penyusunan komentar serta penggambaran dari organisasi program yang telah dibuat. Pemilihan nama pada identifier yang mudah dimengerti merupakan bagian yang paling kritis, karena banyak bahasa pemrograman yang mempunyai keterbatasan pada saat pemberian nama untuk variable.

\section{b. Deklarasi data}

Deklarasi data ditentukan apabila kode telah dibuat dan terdapat sejumlah petunjuk yang dapat digunakan untuk membuat data mudah dimengerti dan mudah pemeliharaannya.

\section{c. Penyusunan perintah}

Penyususnan perintah merupakan bagian dari langkah pengkodean, karena banyak dari bahasa pemrograman yang mengijinkan lebih dari satu perintah dalam satu baris. Pentusunan perintah dapat dipermudah dengan megikuti petunjuk sebagai berikut :

- menghindari pemakaian tes kondisi yang berbelit-belit

- menjabarkan tes pada kondisi yang salah

- menghindari pemakaian perulangan yang berbelit-belit

- menggunakan tanda kurung untuk pembuatan ekspresi logika atau aritmatika

- menggunakan spasi atau simbol yang dapat dibaca untuk menjelaskan isi dari perintah

\section{d. Input / Output}

Petunujuk yang dapat digunakan dalam perncangan dan pengkodean input / output adalah :

- validasi seluruh data input

- cek keusangan terhadap seluruh kombinasi dari item input

- membuat format input dan output yang mudah

e. Efisiensi

Efisiensi merupakan tujuan yang harus dicapai dalam pengkodean, efisiesi yang harus dicapai meliputi :

- efisiensi kode yang merupakan satu kesatuan dengan efisiensi algoritma yang telah didefinisikan pada tahap perancangan.efisiensi memori adalah keefisienan perintah dalam program dan dalam menggunakan memori baik untuk pelaksanaaan ataupun pada penyimpanan data.

\section{Bahasa Pemrograman}


Di dalam pengkodean adalah menterjemahkan desain ke dalam bahasa pemrograman aktual, sebagian besar kesulitan telah harus terpecahkan pada tahap sebelumnya, sehingga pemrogram bebas untuk mencurahkan perhatian penuh untuk pembuatan program.

Bahasa pemrograman merupakan kendaraan yang digunakan untuk berkomunikasi antara manusia dengan mesin komputer. Karakteristik dari bahasa pemrograman mempunyai pengaruh yang penting dari kualitas komunikasi, begitu juga kerekayasaan bahasa pemrograman mempunyai pengaruh yang penting terhadap berhasil tidaknya suatu program yang akan di buat. Pemilihan bahasa pemrograman, yang merupakan hal yang sangat penting bagi pemrogram untuk mulai membuat program. Fungsi dari bahasa pemrograman adalah sebagai media untuk membuat program dan memahami serta sebagai alat komunikasi antara pemrogram dan komputer. Pemilihan bahasa pemrograman harus tepat dan sesuai dengan permasalahan yang ada.

Beberapa kriteria yang digunakan untuk mengevaluasi pemilihan bahasa pemrograman yaitu :

1. Bidang aplikasi yang sedang dikerjakan

2. Kekomplekskan algoritma dan perhitungan

3. Lingkungan dimana perangkat lunak akan diterapkan

4. Pengetahuan staf akan bahasa pemrograman

5. Ketersediaan kompiler yang baik Indra Yatini B : $2001: 9$ )

\section{Testing dan Debugging}

Testing merupakan elemen yang paling kristis dari

perangkat lunak ( program) yang telah selesai dikerjakan. Setelah selesai tahap pengkodean diharapkan program harus tidak mengandung error untuk mendeteksi dan mengoreksi error dapat menjadi usaha yang besar.

Testing adalah menguji program sampai dipenuhi bebas error lewat bermacam-macam kondisi atau dengan input yang hasilnya dapat diprediksi. Testing tidak dapat secara absolut bisa yakin bahwa program adalah benar. Untuk program besar bisa jadi setelah dipakai sekian lama kemudian diketemukan error.

Debugging adalah mengoreksi error yang terdeteksi meliputi menetapkan lokasi kode yang error dan mengoreksinya. Debugging adalah penghilangan semua kesalahan yang ditemukan oleh pengujian dan bisa sangat memakan waktu, terutama pada saat pembuatan program melakukan kecerobohan desain dan pengkodean. Banyak dari debugging melibatkan koreksi kesalahan sehubungan dengan implementasi yang tidak benar dari algoritma dari yang dimaksudkan, tidak ada batasan dari jenis implementasi error yang dibuat, berikut ini beberapa yang paling umum :

\section{Error Spesifikasi}

Program yang ditulis dengan spesifikasi yang tidak benar, misalnya error dalam algoritma.

2. Error Sintax

Muncul dari pengetikan statement yang tidak dimengerti oleh bahasa yang dipakai. Error ini paling mudah dikoreksi karena kompiler dapat memberitahu dibaris keberapa error dapat diketemukan.

3. Error Eksekusi

Dapat muncul pada saat program dijalankan, misalnya division by zero atau kondisi index yang tidak benar atau data yang tidak tepat yaitu data yang tidak sesuai dengan yang diminta program dan validasi input tidak mendeteksi error ini.

4. Error Implementasi

Implementasi yang salah dari algoritma yangdikembangkan,

Misalnya :

- penamaan variabel yang salah

- inisialisasi variable yang tidak benar

- kontrol loop yang tidak benar

- kontruksi bahasa yang tidak dimengerti

Kesulitan utama pada debugging adalah untuk melacak kesalahan, yaitu mencari pernyataan atau bagoan dari suatu program dimana kesalahan terjadi. Begitu letak kesalahan diketahui, sebuah pembacaan mengenai bagian yang salah tersebut biasanya akan mengungkap sumber dari kesalahan yang ada. ( Indra Yatini B : 2001 : $7,130,133$ )

\section{Dokumentasi}

Dokumentasi merupakan informasi dan gambaran tambahan yang sangat membantu untuk memahami sebuah kode yang diberikan. Tujuannya adalah untuk menjadi pedoman dan penjelasan bagi para pemakai. Dokumentasi dapat dibedakan, yaitu dokumentasi internal dan dokumentasi eksternal. Dokumentasi internal sebenarnya 
merupakan bagian kode hanya sebuah eksplansi dari berbagai aspek lewat komentar. Dokumentasi eksternal adalah dalam bentuk manual dan catatan-catatan penting tentang program. Dokumentasi internal dan eksternal harus konsisten satu sama lain dengan kode. ( Indra Yatini B : 2001 : 10 ) (Indra Yatini B : $2001: 11,12$ )

3. RANCANGAN SISTEM

3.1 Flow Of Document

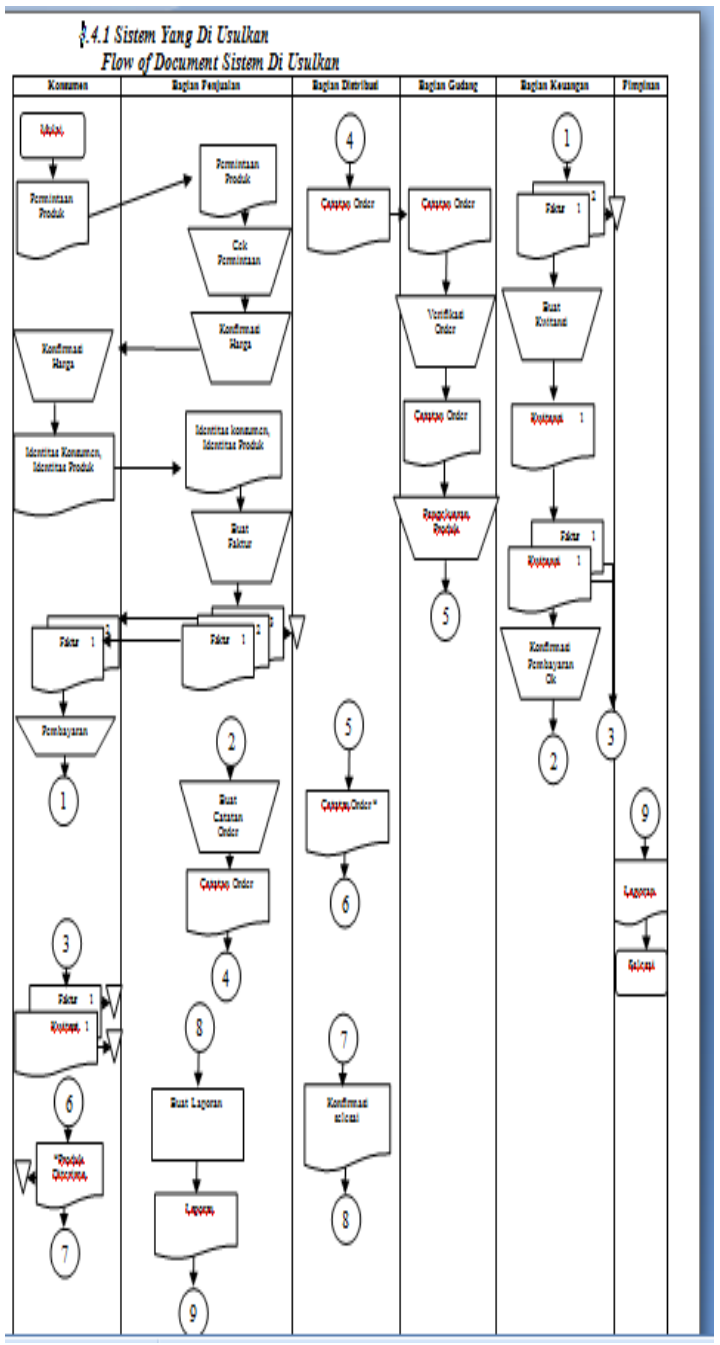

3.2 Context Diagram

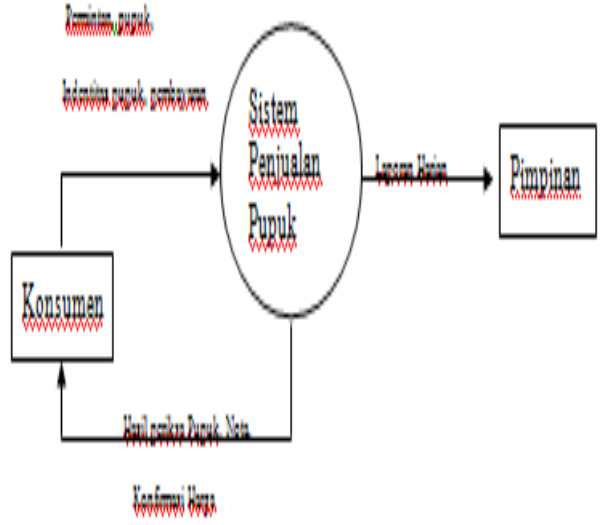

3.3 Diagram Zero (level 1) Sistem Informasi Penjualan Pupuk

Diagram Rinci (level 2) Proses 1.0 Penjualan Pupuk

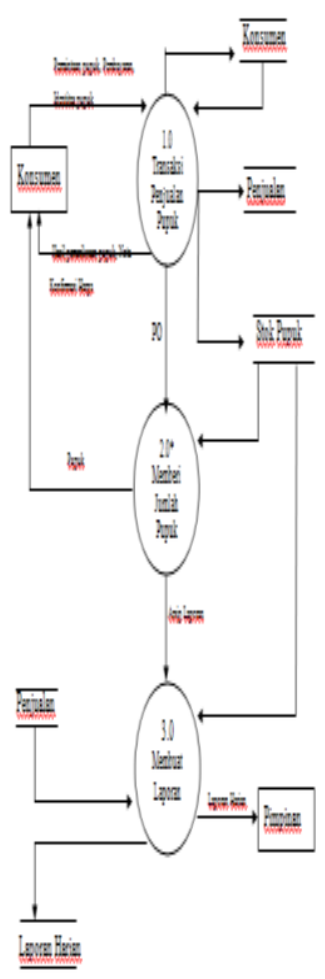

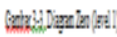

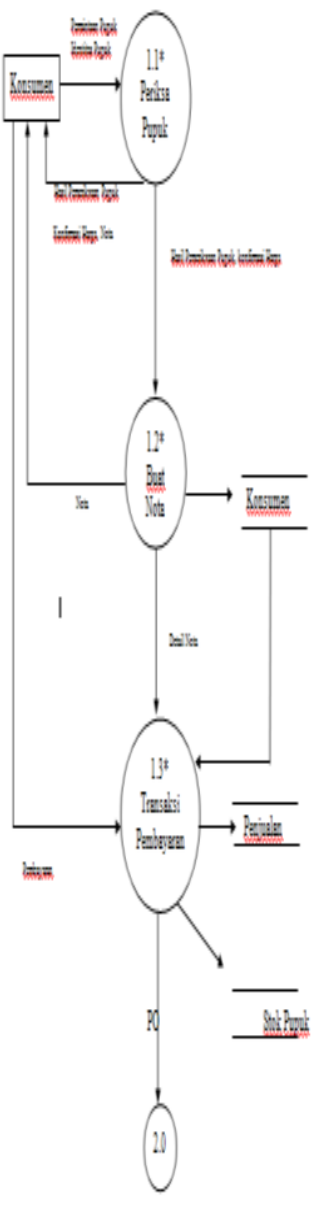

3.3.1 Diagram Rinci (level 2) Proses 3.0 Pembuatan Laporan 


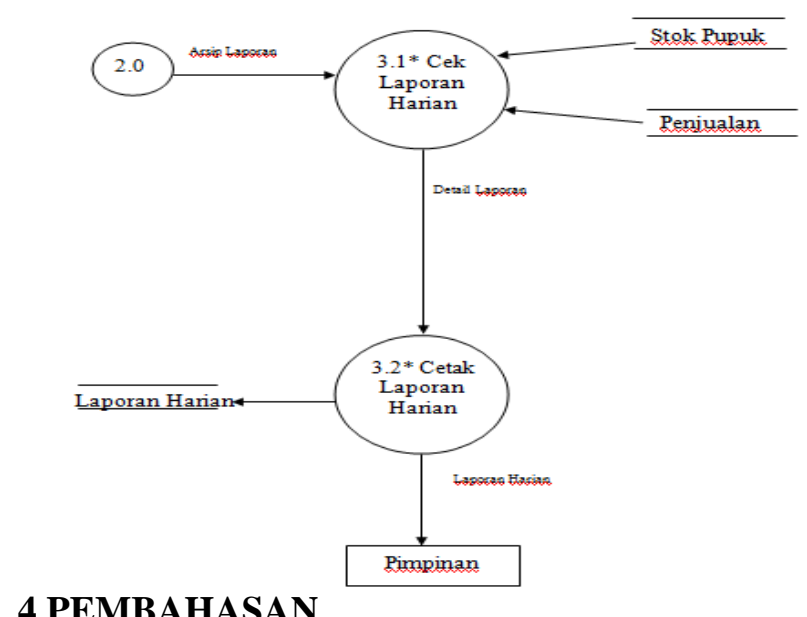

4.PEMBAHASAN

\subsection{Interfaces Aplikasi}

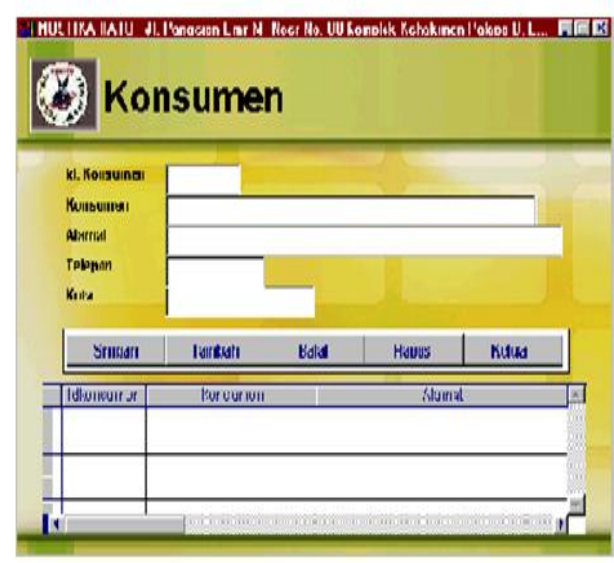

Gambar 4-15. Form Input Transaksi Konsumen

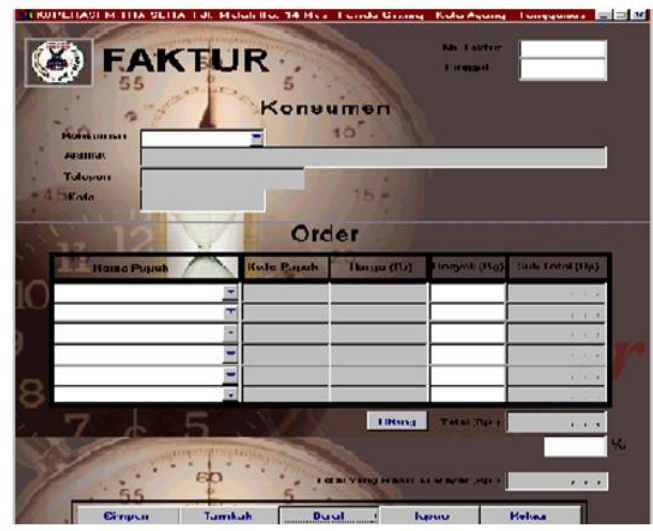

Gambar 4-16. Form Input Transaksi Faktur

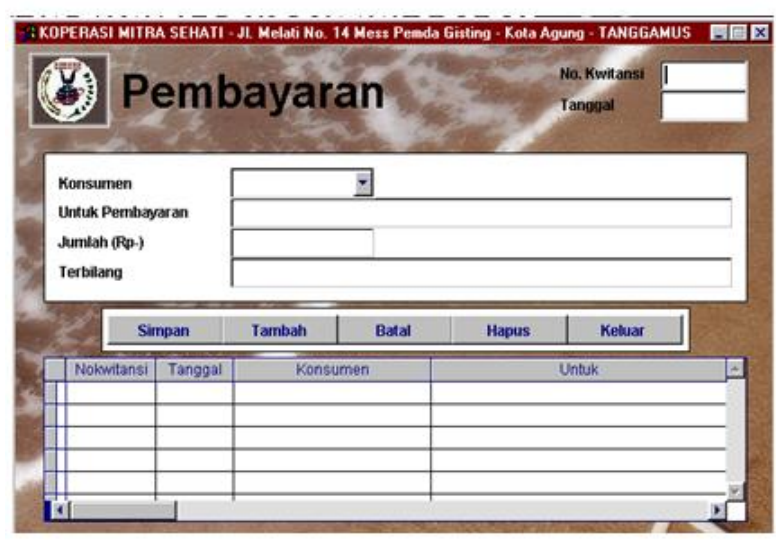

Gambar 4-17. Form Input Tra nsaksi Kwitansi 3

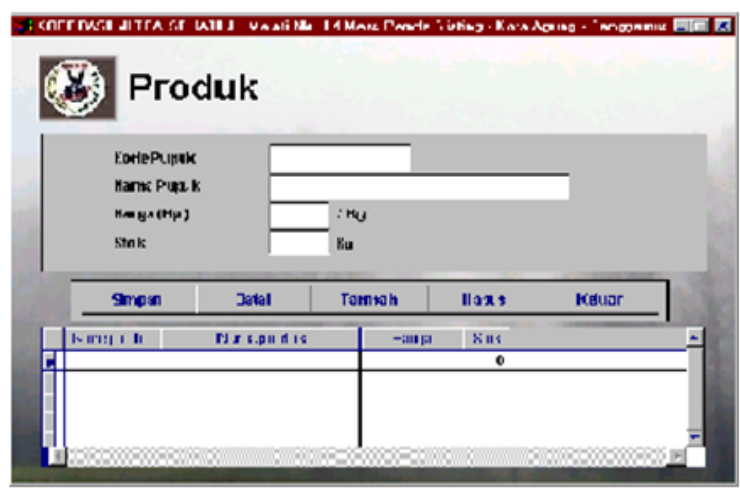

Gambar 4-18. Form Input Transaksi Produk

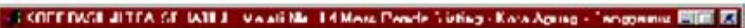

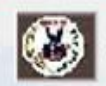

\section{Produk}

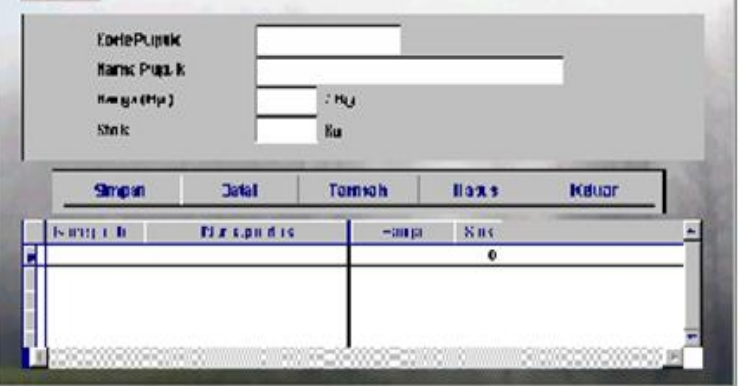

Gambar 4-18. Form Input Transaksi Produk 


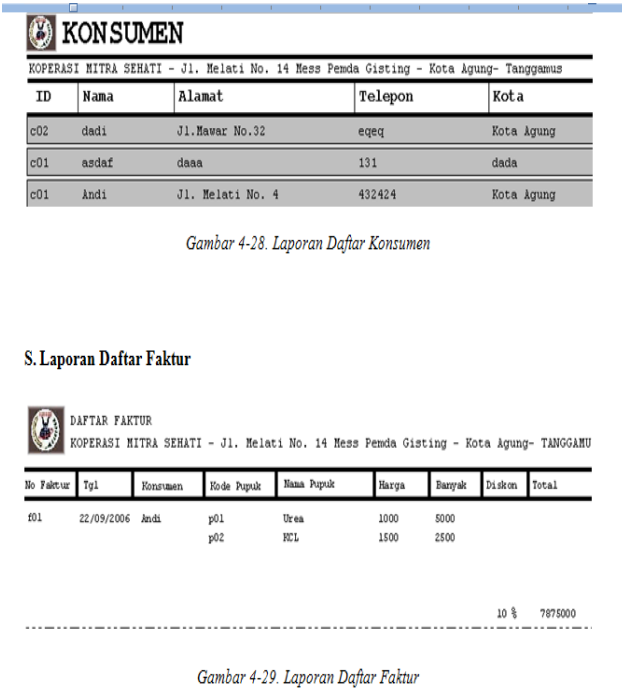

Gambar 4-29. Laporan Daffar Faktur

\section{KESIMPULAN DAN SARAN}

5.

Dari hasil pembahasan yang telah diuraikan pada bagian yang terdahulu, maka penulis dapat mengambil kesimpulan dan saran yang dikaitkan dengan Perancangan Aplikasi Penjualan Pupuk pada Koperasi MITRA SEHATI adalah sebagai beikut:

\subsection{Simpulan}

1. Dengan Sistem Informasi Penjualan Pupuk pada Koperasi MITRA SEHATI akan sangat mendukung dan memperlancar penjualan Pupuk pada Koperasi MITRA SEHATI.

2. Dengan tersedianya Aplikasi Penjualan Pupuk pada Koperasi MITRA SEHATI dapat mengetahui dengan mudah informasi mengenai konsumen, pupuk, serta yang berkaitan dengan penjualan dengan cepat dan akurat.

3. Dengan adanya Aplikasi Penjualan Pupuk pada Koperasi MITRA SEHATI maka dapat dengan mudah mengetahui jumlah penjualan Pupuk serta memudahkan dalam membuat laporan pembukuan penjualan pupuk bulanan.

\subsection{Saran}

Setelah memperhatikan Sistem Informasi Penjualan Pupuk pada Koperasi MITRA SEHATI maka penulis memberikan saran sebagai berikut:

1. Diharapkan operator (User) yang ditugaskan minimal mampu mengoperasikan komputer sistem operasi Windows, dan mampu mengoperasikan sistem ini dengan baik sehingga data-data yang diperlukan dapat menjadi informasi yang benar, dan akurat.

2. Diharapkan sistem ini dapat meningkatkan kinerja karyawan dalam menjalankan tugasnya.
3. Sistem Penjualan Pupuk pada Koperasi MITRA SEHATI merupakan hal yang sangat penting untuk mendukung dalam penjualan pupuk, maka diperlukan pemeliharaan dan evaluasi pada sistem yang ada.

4. Untuk mewujudkan Sistem Informasi Penjualan Pupuk pada Koperasi MITRA SEHATI yang diusulkan atau seperti dalam penulisan ini diharapkan adanya kerja sama dan dukungan dari semua pihak. 